DOI: 10.22363/2313-0245-2019-23-1-54-61

\title{
ПСЕВДОЭКСФОЛИАТИВНЫЙ СИНДРОМ
}

\author{
Б.Б. Бекмирова, М.А. Фролов \\ Российский университет дружбы народов, Москва, Россия
}

На сегодняшний день помутнение хрусталика является одной из распространенных патологий органа зрения. Помутнение хрусталика - катаракта является одной из наиболее частых причин слепоты и слабовидения у детей и взрослых. По мнению большинства авторов, основным методом лечения катаракты остается хирургический. В хирургии катаракты лидирующее место занимает наиболее распространенная методика экстракции катаракты факоэмульсификация. Современный уровень технологии факоэмульсификации позволяет проводить операции менее травматично с полноценным восстановлением зрительных функций. Нет смысла говорить о показаниях имплантации ИОЛ, т.к. в настоящее время существует широкий ассортимент моделей ИОЛ, которые можно имплантировать для всех видов осложненных катаракт. Целесообразно говорить о противопоказаниях, в этом случае хирург принимает решение с учетом материальных возможностей, опыта, совершенства хирургической техники. Существуют различные сопутствующие синдромы при развитии катаракты. Один из синдромов, который встречается при катаракте, является псевдоэксфолиативный синдром. В данном обзоре рассмотрены нерешенные вопросы псевдоэксфолиативного синдрома. Рассмотрены результаты исследований некоторых ученых, анализ данных, клинические случаи и пути решения данной проблемы. В частности, остаются ряд вопросов по поводу тактики введения пациентов до и после операционных вмешательств. Данный синдром, насколько мы знаем, влияет на развитие и исход заболевания. Диагностировать псевдоэксфолиативный синдром на раннем этапе бывает сложно, порой встречаются противоречивые утверждения первичного возникновения синдрома. Остаются открытыми вопросы профилактики постоперационных осложнений, менее травматичных хирургических подходов при различных стадиях ПЭС.

Ключевые слова: катаракта, факодонез, иридодонез, псевдоэксфолиативный синдром, факоэмульсификация катаракты

Ответственный за переписку: Бекмирова Бермет Бекмировна, аспирант кафедры глазных болезней МИ РУДН, 115516, ул. Бакинская, 26 Москва, Россия

E-mail: bermet_bekmirova@mail.ru

Бекмирова Б.Б. ORCID: 0000-0001-5829-2948

Фролов M.A. SPIN-код: 1697-6960, ORCID: 0000-0002-9833-6236

Для цитирования: Бекмирова Б.Б., Фролов М.А. Псевдоэксфолиативный синдром // Вестник Российского университета дружбы народов. Серия: Медицина. 2019. Т. 23. № 1. С. 54 -61. DOI: 10.22363/2313-0245-2019-23-1-54-61.

For citation: Bekmirova B.B., Frolov M.A. (2019). Pseudoexpholiative Syndrome. RUDN Journal of Medicine, 23 (1), $54-61$. DOI: $10.22363 / 2313-0245-2019-23-1-54-61$.

На сегодняшний день из всех глазных заболеваний наиболее распространенной патологией является заболевание хрусталика, которое называется катарактой. Причиной развития данной патологии во многих цивилизованных странах мира являются неблагоприятные экологические факторы, а также факторы риска населения, такие как курение, сахарный диабет, применение 
кортикостероидов (длительное или системное), внутриглазная хирургия и т.д. [1].

По данным ВО3, число пациентов, нуждающихся в хирургическом лечении, каждый год возрастает. На сегодняшний день более 260 тысяч операций в год проводят по поводу катаракты [2]. Хирургическое лечение проводят тем пациентам, у которых снижены зрительные функции, наблюдается ограничение работоспособности, которые испытывают дискомфорт в повседневной жизни.

В настоящее время существуют два различных метода в хирургии катаракты. Это интракапсулярная и экстракапсулярная экстракция катаракты [3]. Наиболее распространенной методикой экстракции катаракты является факоэмульсификация.

Метод факоэмульсификации занимает лидирующее место в современной катарактальной хирургии. Впервые данная техника была разработана Kelman в 1967 году. Однако за всю историю своего существования данная техника к настоящему моменту претерпела существенные изменения [4].

В каждой разработке имеются свои преимущества и недостатки. В данной методике преимуществами является малый «самогерметизирующийся» разрез, отсутствие необходимости наложения швов, низкая частота операционных и послеоперационных осложнений, высокая острота зрения в послеоперационном периоде, сокращения сроков реабилитации пациентов и т.д. $[5,6]$.

Современная технология хирургии катаракты с использованием малых разрезов и имплантации эластичных интраокулярных линз повысила уровень результативности хирургии катаракты [7]. Остаются открытыми вопросы профилактики развития катаракты, а также ее медикаментозного лечения. По мнению большинства ученых, пероральное применение поливитаминов в процессе катарактогенеза, а также инстилляции препаратов не выявил достоверной реверсии [8].
Один из синдромов, встречающихся при катаракте, является псевдоэксфолиативный синдром, который влияет на развитие и исход заболевания независимо от ее этиологии. Частота сочетаний двух заболеваний варьируется от 0,4 до $37 \%$. При данном синдроме наблюдаются несостоятельность связочного аппарата хрусталика с симптомами иридодонеза, факодонеза $[9,10]$.

Первое описание данного синдрома связано с именем J. Lindberg (1917), который в результате исследования группы пациентов указал на наличие в глазу серо-голубых хлопьев на зрачковом крае радужной оболочки у $6,6 \%$ лиц преклонного возраста, у 20\% больных старческой катарактой и у 50\% больных хронической глаукомой [11]. Позже Dvorak-Theobald (1954) ввела термин «псевдоэксфолиация хрусталика» [12].

Псевдоэксфолиативный синдром - это системное дистрофическое заболевание, ассоциированное с возрастом, для которого характерно поражение преимущественно переднего сегмента глаза $[13,14]$. Однако в дальнейшем было установлено, что проявления депонирования аномального материала на поверхности различных структур глаза встречаются не только на всем переднем сегменте глаза, но и в других органах, включая сердце, почки, печень, оболочки мозга [15].

В 1956 году один из ученых наблюдал пациентов с простой глаукомой, у которых были отложения псевдоэксфолиативного материала как на передних структурах глаза, так и на задних, и пришел к мнению, что причина их образования общая. Автор называл «псевдоэксфолиативную» капсулу «старческой эксфолиацией» [16].

ПЭС диагностируется во всем мире, географическое положение и климат не влияют на возникновение этой патологии [17].

По данным исследования авторов в центральной России, этот синдром встречается у пациентов старше 50 лет - 6,2\% случаев, и у пациентов в возрасте 70 лет - в 13,9\% случаев. П. Фролов, Г. Хамитова (1984) в результате своих исследова- 
ний в Татарстане показали встречаемость псевдоэксфолиативного синдрома у $5,8 \%$ обследованных лиц старше 40 лет [18].

По результатам исследования одного из ученых частота проявлений синдрома во многом зависит от возрастной категории обследованных больных. В результате проведения профилактического осмотра у групп пациентов в количестве 1407 было установлено, что у лиц от 50-59 лет выявлен 1\% случаев, от 60 - 69 лет - 6,5\% случаев, в 70 лет и старше - 13,9\% случаев проявления ПЭС [10].

Патологические процессы при ПЭС могут наблюдаться как на передних отделах, так и в задних отделах глаза.

Есть мнение о появлениях клинических признаков на роговице в более поздних стадиях. Однако некоторые авторы подтверждают роль эндотелия роговицы в синтезе псевдоэксфолиативного синдрома [19].

На задней поверхности роговицы могут откладываться гранулы пигмента в виде «веретена Крукенберга», причиной этому могут быть депигментации заднего эпителия радужки, а также выброса пигмента из задней камеры в переднюю, в момент реакции зрачка на свет и аккомодацию (симптом «пигментной пыли»), а также отложение во всех структурах переднего отдела глаза [20].

Один из авторов, изучая морфологию эндотелия роговицы и ее толщину, пришел к выводу об уменьшении количества эндотелиальных клеток и истончении центральной части роговицы [21]. В результате у некоторых пациентов с данным синдромом наблюдаются конгломераты псевдоэксфолиативного материала в составе десцеметовой мембраны.

Также ранним проявлением ПЭС является дисперсия пигмента по поверхности эндотелия роговицы, радужной оболочки и капсулы хрусталика. Данное явление отражает дистрофические изменения заднего эпителиального листка радужной оболочки и распыление его пигмента за счет конвекционного тока внутриглазной жидкости [22].

Накопление фиброзных волокон эксфолиативного материала в строме радужки приводит к дегенеративным изменениям сфинктера и дилататора зрачка. Патологические изменения в мышцах радужки, в сфинктере и в дилататоре коррелируют со степенью ригидности зрачка [23]. Перипупиллярная атрофия возникает за счет освобождения и дисперсии меланиновых гранул вследствие разрыва клеточных мембран пигментного листка радужки, которая приводит к дегенерации и закупорке кровеносных сосудов [24].

При повреждении клеток пигментного эпителия радужки происходит ее атрофия, которая приводит к эффекту трансиллюминации в области сфинктера и зрачка. Данный эффект при выраженной депигментации появляется не только в зоне сфинктера, но и по всей поверхности радужки (данная картина называется «звездное небо») [25].

Данный синдром затрагивает и трабекулярный аппарат. При проведении гониоскопии в области трабекулы видна чрезмерная пигментация. Данный пигмент накапливается в области линии Швальбе и впереди от нее. Пигмент может быть в виде единичных или множественных хаотичных линий. Данный пигмент носит название линия Сампаолези [26].

В настоящее время существуют несколько классификаций псевдоэксфолиативного синдрома, разделенных на несколько типов в зависимости от положенных в их основу признаков. Среди них классификация Н.Б. Шульпина, И.К. Намазова (1990) [27]. На территории РФ широко известна классификация Е.Б. Ерошевской (1997) [28], классификация G.O.H. Naumann et al. (1998) [29], H.M. Nizankowska (2001) [30], Нестерова (2008) [31], Х.П. Тахчиди, Э.В. Егоровой и Д.Г. Узунян (2004) [32].

Однако не стоит забывать об осложнениях. Сопутствующая катаракте деструкция капсулы и связочного аппарата хрусталика при псевдоэксфолиативном синдроме может быть резуль- 
татом осложнений, таких как: в ходе операции дистрофия радужки, ригидность зрачка и слабость цинновых связок, риск разрыва капсулы хрусталика, сублюксация ядра хрусталика в стекловидное тело, выпадения стекловидного тела; в послеоперационном периоде - дистрофия дренажной системы глаза, риск декомпенсации гидродинамики [33].

Что касается зрачка при псевдоэксфолиативном синдроме, как уже было сказано, становится ригидным и плохо поддается расширению при предоперационной премедикации. Расположение данного синдрома на краю зрачка отмечено у $31-94 \%$ пациентов. Некоторыми авторами отмечено нахождение данного материала у края зрачка даже при полной сохранности пигментной каймы. Чем дальше развивается данный синдром, тем труднее расширить зрачок и создаются дополнительные трудности при хирургических операциях. В первую очередь удлиняется время и риск осложнений.

На сегодняшний день существуют различные способы расширения зрачка, множественные радиальные кератотомии, стрейчинги, ирис-ретракторы, но проблема все равно остается нерешенной, т.к. хирургу требуется дополнительно делать разрезы, которые могут повредить сфинктер радужки, из-за чего, в свою очередь, можно получить косметические проблемы.

Один из способов расширения зрачка был описан авторами [34] в 2013 г. Они разработали ирис-ретрактор ИР-5 и ИР-6, представляющий собой 2 симметричных лепестка прямоугольной формы, углы которых скрючены, и 2 других лепестка конусообразной формы [35]. При имплантации данного ирис-ретрактора форма зрачка приобретает квадратную форму диагональю 5,0 мм и 6,0 мм. Данный ирис-ретрактор безопасно и просто имплантируется с помощью специального инжектора, который имеет адаптированные размеры и рабочую часть под данный ретрактор. И с помощью 2 атравматичных инструментов вводят в переднюю камеру, предварительно сжимая в области конструкции.
В процессе патогенеза ПЭС, по мнению многих авторов, играют роль иммунометаболические и воспалительные процессы. Доказано, что у пациентов с признаками ПЭС в слезной жидкости наблюдали повышение концентрации ИЛ-6, ИЛ-10, острофазного белка лактоферррина, секреторного иммуноглобулина класса А [36].

Несмотря на многочисленные работы авторов проведенных по поводу изучения этиологии и патогенеза данного синдрома все равно присутствует процент осложнений во время и постоперационном периоде. Это связано с недостаточно точной диагностикой в предоперационном периоде.

Исходя из анализа обзора литературы, можно сделать следующие выводы. Вышеизложенные клинические проявления псевдоэксфолиативного синдрома недостаточно раскрывают начало процесса. Остаются открытыми вопросы тактики введения пациентов до операции и в послеоперационном периоде. Изучение возможности реабилитации пациентов с осложненной катарактой на фоне ПЭС, разработка методов профилактики поздних операционных осложнений являются актуальными задачами.

\section{БИБЛИОГРАФИЧЕСКИЙ СПИСОК}

1. Maraini G., D'Erno F., Auricchio G. In: Guidelines for the clinical investigation of anticataract drugs in senile cataract. World Health Organization, Copenhagen 1985.

2. Агафонова В.В. Коррекция аметропий интраокулярными факичными линзами: дис. ... д-ра мед. наук. М., 2006. $350 \mathrm{c}$.

3. Бабичева Р.Г., Аверьянов В.И. О технике хирургического лечения катаракты у детей // Вестн. офтальмол. 1982. C. $26-28$.

4. Головин А.В. Клинико-функциональные результаты микроинвазивной технологии факоэмульсификации с имплантацией интраокулярной линзы: автореф. дис. ... канд. мед. наук. М., 2011. 27 с.

5. Малюгин Б.Э. Медико-технологическая система хирургической реабилитации пациентов с катарактой на основе ультразвуковой факоэмульсификации с имплантацией интраокулярной линзы: дис. ... докт. мед. наук. М., 2002. 298 с.

6. Ходжсаев Н.С. Хирургия катаракты с использованием малых разрезов: клинико-теоретическое образование: дис. ... д-ра мед. наук. М., 2000. 278 с. 
7. Малюгин Б.Э., Линник Л.Ф., Егорова Э.В., Копаева В.Г., Толчинская А.И. Проблемы хирургии катаракты и интраокулярной коррекции: достижения отечественной школы и современные тенденции развития // Вестник Российской академии медицинских наук. 2007. № 8. С. 9-16.

8. Christen W., Glynn R., Sperduto R. et al. Age-related cataract in a randomized trial of beta-carotene in women // Ophthalmic Epidemiol. 2004. V. 11. P. 401-412.

9. Журавлев В.С. Биомикроскопические и гистохимические исследования псевдоэксфолиаций в переднем отеле глаза // Вестн. Офтальмол. 1967. № 4. С. $58-60$.

10. Кроль Д.С. Псевдоэксфолиативный синдром и эксфолиативная глаукома: Автореф. дисс. ... д-ра мед. наук. M., 1970. $32 \mathrm{c}$.

11. Lindberg J.G. Kliniska undersokninger over depigment tering av pupillarra - unden och genomlys — barket av iris vid fall av alderstarr samit I normal ogon hos gamla personer. Diss. Helsingfors, M.D. Thesis, 1917.

12. Dvorak-Theobald G. Pseudoexfoliation of the lens capsule: Relation to true exfoliation of the lens capsule as reported in the literature and the role in the production of glaucoma capsulocuticulare // Amer. J. Ophthalmol. 1954. V. 37. № 1. P. $1-12$.

13. Ritch R. Exfoliation syndrome // Curr. Opin. Ophthalmol. 2001. Apr. V. 12. № 2. P. 124-130.

14. Dan J., Belyea D., Gertner G., Leshem I., Lusky M., Miskin R. Plasminogen activator inhibitor - I in the aqueous humor of patients with and without glaucoma // Arch. Ophthalmol. 2005. V. 123. P. 220-224.

15. Hietanen J., Soisalon-Soininen S., Kivela T., Tarkkanen A. Evaluation of the clinical assotiation between exfoliation syndrome and abdominal aortic aneurysm // Acta Ophthalmol. Scand. 2002. Dec. V. 6. P. 617-619.

16. Sunde O.A. On the so-called senile exfoliation of the anterior lens capsule: a clinical and anatomical study // Acta Ophthalmol. Scand. 1956. № 45. P. 45-54.

17. Allingham R.R., Loftsdottir M.,Gottfredsdottir M.S., Thorgeirsson E., Jonnason T., Hodge W.G., Damji K.F., Stefansson E. Pseudoexfoliation syndrome in Icelandic families // Br. J. Ophthalmol. 2001. Jun V. 85. № 6. P. $702-707$.

18. Damji K.F., Bains H.S., Steffason E., et al. Is pseudoexfoliation syndrome inherited? A review of genetic and nongenetic factors and new observation // Ophthalmol. genet. 1998. № 19. P. 175-185.

19. Naumann G.O.H., Schlotzer-Schrehardt U. Keratopathy in pseudoexfoliation syndrome as a cases of corneal endothelial decompensation: clinic-pathologic study // Ophthalmology. 2000. Jun. V. 107. № 6. P. 1111-1124.
20. Schlotzer-Schrehardt U.M., Naumann G.O.H. Perspective ocular and systematic pseudoexfoliation synfrome // Am. J. of Ophthalmol. 2006. V. 141. № 5. P. 921-937.

21. Inoue K., Okugawa K., Oshika T. et al. Morphological study of corneal endothelium and corneal thickness in pseudoexfoliation syndrome // Jpn. J. Ophthalmol. 2003. V. 47. № 3. P. 235-239.

22. Kansky J., Mc Allister J.A., Salomon J.F. Jaskra-Kolorowy podrecznik diagnostyki I terapii. Wroclaw: Wydawnictwo Medyczne Urban \& Partner, 1998. $173 \mathrm{~s}$.

23. Naumann G.O.H., Schlotzer-Schrehardt U., Kuchle M. Pseudoexfoliation syndrome for the comprehensive ophthalmologist: intraocular and systemic manifestations // Ophthalmology. 1998. V. 105. P. 951-968.

24. Asano N., Schlotzer-Schrehardt U., Naumann G.O.H. A histopathologic study of iris changes in pseudoexfoliation syndrome // Ophthalmology. 1995. V. 102. P. $1279-1290$.

25. Tarkkanen A., Hietanen $J$. The impact of exfoliation syndrome on therapeutic efficacy in open angle glaucoma // Current Opinion in Ophthalmol. 1995. V. 6. № 11. P. $10-14$.

26. Puska $P$. The amount of lens exfoliation and chamber angle pigmentation in exfoliation syndrome with or without glaucoma // Acta Ophthalmol. Scan. 1995. V. 73. P. 226-232.

27. Шульпина Н.Б, Шамазова И.К. Псевдоэксфолиативный синдром, его значение в диагностике и лечении катаракты // Вестник офтальмологии. 1990. С. 9.

28. Ерошевская Е.Б. Интраокулярная коррекция афакии у больных первичной открытоугольной глаукомой: дис. д-ра мед. наук. Самара, 1997. 240 с.

29. Naumann G.O.H., Schlotzer-Schrehardt U., Kuchle M. Pseudoexfoliation syndrome for the comprehensive ophthalmologist: intraocular and systematic manifestations // Ophthalmology. 1998. V. 105. № 6. P. 951-968.

30. Nizankowska H.M. Jaskra Wspolczesne zarady rozpoznawania. Wroclaw: Gornicki Wydawnictwo Medyczne, 2001. P. 107.

31. Нестеров А.П. Глаукома. М.: МИА, 2008. 360 с.

32. Тахчиди Х.П., Егорова Э.В., Узунян Д.Г. Ультразвуковая биомикроскопия в диагностике патологии переднего сегмента глаза. М.: Микрохирургия глаза. $2007.128 \mathrm{c}$

33. Skuta G.L., Parrish R.K., Hodapp E.H., Foster R.K., Rockwood E.J. Zonular dialysis during extracapsular cataract extraction in pseudoexfoliation syndrome // Arch. Ophthalmol. 1987. V. 105. P. 632-634.

34. Гринев А.Г., Хлопотов С.В., Мальков А.В., Бабинкова H.A. Первый опыт применения ирис-ретракто- 
ров новой конструкции // Современные технологии катарактальной и рефракционной хирургии - 2010; Сб. научн. статей / ФГУ «МНТК Микрохир гл.». М., 2010. С. $46-50$.

35. Гринев А.Г., Хлопотова С.В., Мальков А.В., Бабинкова Н.А. Ирис-ретрактор // Патент РФ на полезную модель № 101917, МПК А61F9/007, опубл.: 10.02.2011. Бюл. № 4.

36. Тахчиди Х.П., Баринов Э.Ф., Агафонова В.В. Патология глаза при псевдоэксфолиативном синдроме. М.: Офтальмология, 2010. 156 с.

(C) Бекмирова Б.Б., Фролов М.А., 2019

This work is licensed under a Creative Commons Attribution 4.0 International License

Поступила 11.01.2019

Принята 14.03.2019

DOI: 10.22363/2313-0245-2019-23-1-54-61

\title{
PSEUDOEXPHOLIATIVE SYNDROME
}

\author{
B.B. Bekmirova, M.A. Frolov \\ Peoples' Friendship University of Russia, Moscow, Russia
}

\begin{abstract}
Today, the clouding of the lens is one of the common pathology of the organ of vision. The clouding of the lenscataract is one of the most common causes of blindness and low vision in children and adults. According to most authors, the main method of cataract treatment is surgical. In modern cataract surgery, the leading place is occupied by the most common cataract extraction method, phacoemulsification. The modern level of phacoemulsification technology made it possible to perform operations less traumatic, gave a full restoration of visual functions. It makes no sense to talk about the indications of IOL implantation, since Currently, there is a wide range of IOL models that can be implanted for all types of complicated cataracts. It is advisable to talk about contraindications, in this case, the surgeon makes a decision based on the material capabilities, experience, and perfection of the surgical technique. There are various associated syndromes in the development of cataracts. One of the syndromes that occurs in cataracts is the pseudo-excoliation syndrome. This review addresses the unresolved issues of pseudoexfoliation syndrome. The results of studies of some scientists, data analysis, clinical cases and ways to solve this problem are considered. In particular, a number of questions remain about the tactics of patient administration before and after surgical interventions. This syndrome, as far as we know, affects the development and outcome of the disease. It is sometimes difficult to diagnose pseudo-excoliation syndrome at an early stage, sometimes contradictory statements about the initial appearance of the syndrome are encountered. The issues of prevention of postoperative complications, less traumatic surgical approaches at various stages of PES remain open.
\end{abstract}

Corresponding Author: Bekmirova Bermet Bekmirovna, post-graduated student of the Department of Eye Diseases PFUR, 115516, Bakinskaya 26 street Moscow, Russia

E-mail: bermet_bekmirova@mail.ru

Bekmirova B.B. ORCID: 0000-0001-5829-2948

Frolov M.A. SPIN-код: 1697-6960, ORCID: 0000-0002-9833-6236

\section{REFERENCES}

1. Maraini G., D’Erno F., Auricchio G. In: Guidelines for Senile Cataract. World Health Organization, Copenhagen 1985.

2. Agafonova V.V. Correction of ametropia with intraocular phakic lenses: Doct Diss. M., 2006. P. 350.
3. Babicheva R.G., Averyanov V.I. On the technique of surgical treatment of cataracts in children. Vestn. Ophthalmol. 1982. P. 26-28.

4. Golovin A.V. Clinical and functional results of microinvasive phacoemulsification technology with intraocular lens implantation: author. Doct. Diss. M., 2011. P. 27. 
5. Malyugin B.E. Medico-technological system of surgical rehabilitation of patients with cataracts on the basis of ultrasound phacoemulsification with the implantation of an intraocular lens. Doct. Diss. M., 2002. P. 298.

6. Khojaev N.S. Cataract surgery with the use of small incisions: clinical and theoretical education. Doct. Diss. M., 2000. P.278.

7. Malyugin B.E., Linnik L.F., Egorova E.V., Kopayeva V.G., Tolchinskaya A.I. Problems of cataract surgery and intraocular correction: the achievements of the national school and modern development trends. Bulletin of the Russian Academy of Medical Sciences. 2007. № 8. P. 9-16.

8. Christen W., Glynn R., Sperduto R. et al. Age-related cataract in a randomized trial of beta-carotene in women. Ophthalmic Epidemiol. 2004. V. 11. P. 401-412.

9. Zhuravlev V.S. Biomicroscopic and histochemical studies of pseudo-exfoliation in the anterior hotel of the eye. Vestn. Ophthalmol. 1967. № 4. P. 58-60.

10. Krol D.S. Pseudoexfoliative syndrome and exfoliative glaucoma. Doct. Diss. M., 1970. P. 32.

11. Lindberg J.G. Kliniska undersokninger over depigmenttering av pupillarra - unden och genomlys - barket av iris vid fall av alderstarr samit I orang hos gamla personer. Diss. Helsingfors, M.D.Thesis. 1917.

12. Dvorak-Theobald G. Capsule capsules: Relaced with the lens of the capsule. J. Ophthalmol. 1954. V. 37. № 1. P. $1-12$.

13. Ritch R. Exfoliation syndrome. Curr. Opin. Ophthalmol. 2001. Apr. V. 12. № 2. P. 124-130.

14. Dan J., Belyea D., Gertner G., Leshem I., Lusky M., Miskin R. Plasminogen activator inhibitor. Arch. Ophthalmol. 2005. V. 123. P. 220-224.

15. Hietanen J., Soisalon-Soininen S., Kivela T., Tarkkanen A. Evaluation of the clinical trial of exothermic syndrome and abdominal aortic aneurysm. Acta Ophthalmol. Scand. 2002. Dec. V. 6. P. 617-619.

16. Sunde O.A. On the so-called anterior lens capsule: a clinical and anatomical study. Acta Ophthalmol. Scand. 1956. № 45. P. $45-54$.

17. Allingham R.R., Loftsdottir M., Gottfredsdottir M.S., Thorgeirsson E., Jonnason T., Hodge W.G., Damji K.F., Stefansson E. Pseudoexfoliation syndrome in Icelandic families. Br. J. Ophthalmol. 2001 Jun V. 85. № 6. P. 702-707.

18. Damji K.F., Bains H.S., Steffason E., et al. Is pseudoexfoliation syndrome inherited? A review of genetic factors and nongenetic factors and new observation. Ophthalmol. genet. 1998. № 19. P. 175-185.

19. Naumann G.O.H., Schlotzer-Schrehardt U. Keratopathy, pathologic study. Ophthalmology. 2000. Jun. V. 107. № 6. P. 1111-1124.
20. Schlotzer-Schrehardt U.M., Naumann G.O.H. Perspective ocular and systematic pseudoexfoliation synfrome. Am. J. of Ophthalmol. 2006. V. 141. № 5. P. 921—937.

21. Inoue K., Okugawa K., Oshika T. et al. Morphological study of corneal endothelium and corneal thickness in pseudoexfoliation syndrome. Jpn. J. Ophthalmol. 2003. V. 47. № 3. P. $235-239$.

22. Kansky J., Mc Allister J.A., Salomon J.F. Jaskra - Kolorowy podrecznik diagnostyki I terapii. Wroclaw: Wydawnictwo Medyczne Urban \& Partner, 1998. P. 173.

23. Naumann G.O.H., Schlotzer-Schrehardt U., Kuchle M. Pseudoexfoliation syndrome for the ophthalmologist: intraocular and systemic manifestation. Ophthalmology. 1998. V. 105. P. $951-968$.

24. Asano N., Schlotzer-Schrehardt U., Naumann G.O.H. A histopathologic study of iris changes in pseudoexfoliation syndrome. Ophthalmology. 1995. V. 102. P. 12791290.

25. Tarkkanen A., Hietanen J. The impact of exfoliation syndrome in current angle. Current Opinion in Ophthalmol. 1995. V. 6. № 11. P. 10-14.

26. Puska P. The Act of Ophthalmol. Puska P. The amount of lens exfoliation syndrome with or without glaucoma. Scan. 1995. V. 73. P. 226-232.

27. Shulpina N.B., Shamazova I.K. Pseudo-excoliation syndrome, its importance in the diagnosis and treatment of cataracts. Ophthalmology Bulletin. 1990. P. 9.

28. Eroshevskaya E.B. Intraocular correction of aphakia in patients with primary open-angle glaucoma: Doct. Diss. Samara, 1997. P. 240.

29. Naumann G.O.H., Schlotzer-Schrehardt U., Kuchle M. Pseudoexfoliation syndrome for the ophthalmologist: intraocular and systematic manifestation. Ophthalmology. 1998. V. 105. № 6. P. 951-968.

30. Nizankowska H.M. Jaskra Wspolczesne zarady rozpoznawania. Wroclaw: Gornicki Wydawnictwo Medyczne, 2001. P. 107.

31. Nesterov A.P. Glaucoma. M.: MIA, 2008. 360 p.

32. Takhchidi Kh.P., Egorova E.V., Uzunyan D.G. Ultrasound biomicroscopy in the diagnosis of pathology of the anterior segment of the eye. M.: Eye microsurgery. 2007. P. 128.

33. Skuta G.L., Parrish R.K., Hodapp E.H., Foster R.K., Rockwood E.J. Zonular dialysis during extracapsular cataract extraction in pseudoexfoliation syndrome. Arch. Ophthalmol. 1987. V. 105. P. 632-634.

34. Grinev A.G., Cares S.V., Malkov A.V., Babikova N. The first experience of application of iris-retractors new design. Modern technologies in cataract and refractive surgery - 2010; Sat. scientific. articles / FGU "MNTK" Microchir Chapter“. M., 2010. P. 46-50. 
35. Grinev A.G., Klopotov S.V., Malkov A.V., Babikova N. Iris-retractor. RF Patent for useful model No. 101917, IPC A61F9/007, publ.: 10.02.2011. Byul. No. 4.
36. Takhchidi H.P., Barinov E.F., Agafonova V.V. Pathology of eyes with pseudoexfoliation syndrome. M.: Ophthalmology, 2010. $156 \mathrm{p}$.

(C) B.B. Bekmirova,. Frolov M.A., 2019 This work is licensed under a Creative Commons Attribution 4.0 International License

Received 11.01.2019

Accepted 14.03.2019 